\title{
A human touch to snakebite antivenoms
}

\section{Laustsen, Andreas Hougaard}

Published in:

Toxicon

Link to article, DOI:

10.1016/j.toxicon.2018.10.061

Publication date:

2019

Document Version

Peer reviewed version

Link back to DTU Orbit

Citation (APA):

Laustsen, A. H. (2019). A human touch to snakebite antivenoms. Toxicon, 158(Suppl. 1), S16-S16. [52]. https://doi.org/10.1016/j.toxicon.2018.10.061

\section{General rights}

Copyright and moral rights for the publications made accessible in the public portal are retained by the authors and/or other copyright owners and it is a condition of accessing publications that users recognise and abide by the legal requirements associated with these rights.

- Users may download and print one copy of any publication from the public portal for the purpose of private study or research.

- You may not further distribute the material or use it for any profit-making activity or commercial gain

- You may freely distribute the URL identifying the publication in the public portal

If you believe that this document breaches copyright please contact us providing details, and we will remove access to the work immediately and investigate your claim. 
A human touch to snakebite antivenoms

Snakebite is a neglected tropical disease of importance to global public health. Each year, snakebite causes mortality and morbidity to hundreds of thousands of victims, particularly in poor, rural settings in developing countries. Antisera derived from immunized animals remain the only effective treatment option against snakebite. Unfortunately, such antisera are expensive to manufacture and may inflict severe adverse reactions in human victims due to their heterologous nature, making them incompatible with the human immune system. For many years, advances have been made within development of novel snakebite envenoming therapies, including the use of novel immunization techniques, small molecule inhibitors, and antibody discovery. However, none of these advances have yet reached the clinic, possibly because snake venoms consist of myriads of medically important toxins belonging to different protein families, making snake venoms some of the most complex drug targets known to man.

Here, some of the recent advances within development and successful in vivo testing of fully human IgG antibodies against elapid neurotoxins will be presented, and strategies for developing antibody-based recombinant antivenoms guided by omics technologies (including toxicovenomics and high-density peptide microarray technology) will be discussed. Perspectives will be provided on production technologies for novel biotechnology-based antivenoms, and an overview of the bottlenecks in bringing a new generation of envenoming therapies to the clinic will be provided. 